\title{
PANEL DISCUSSIONS
}

\section{Can you Find Yourself in the Stacks? \\ Building Diverse Collections in Religion and Theology}

Suzanne Estelle-Holmer, Yale University

Amy Limpitlaw, Boston School of Theology

Michelle Spomer, Pittsburgh Theological Seminary

\begin{abstract}
ABSRACT The past year has brought renewed attention to the need for academic library collections to support an emphasis on diversity, equity, and inclusivity (DEI) in the curriculum and to reflect the increasing diversity among students and faculty. The urgent calls for maximum inclusivity and diversity in all aspects of theological education have led collection development librarians to re-examine and re-calibrate their collecting practices. Three librarians offer practical suggestions on how to approach the challenges of developing diverse collections by engaging with key stakeholders, aligning collecting with the institution's mission and/or vision statements, utilizing approval plans, and promoting collections through outreach and diversity programming.
\end{abstract}

\section{SUPPORTING DIVERSITY IN THE CURRICULUM AT YALE DIVINITY SCHOOL}

Suzanne Estelle-Holmer, Yale University

Issues of diversity, equity, and inclusion are not new to our profession, yet there is still relatively little literature devoted to the challenges of developing diverse general collections in an academic 
context (see bibliography below). Some of this reflects the slow pace at which our institutions have admitted new voices and perspectives into academic discourse and, hence, into the curriculum. However, the events of the past year, including the rise of the Black Lives Matter movement, the murder of George Floyd, and the devastating effects of the COVID-19 global pandemic on racial minorities and the poor, has hastened calls for change in theological education. Much of this work has focused on a re-evaluation of the curriculum. At the Yale Divinity School, the number of minority faculty rising in the ranks has increased over the past ten years, and we now have faculty who teach Black and Womanist theology, ethics, and preaching, as well as Asian theologies and Latin American religions. This has enabled the school to offer courses every semester on topics that treat specific religious or ethnic groups. However, the call is now for diversity, equity, and inclusion (DEI) to be a major component of most, if not all, foundational courses. This offers the collection development librarian the opportunity to partner with faculty and students to systematically explore new areas of collecting. Building diverse collections is a tangible way that the library can contribute to a school's DEI efforts. Here I describe some preliminary steps to take in determining priorities and next steps as your institution implements more diverse curricular offerings.

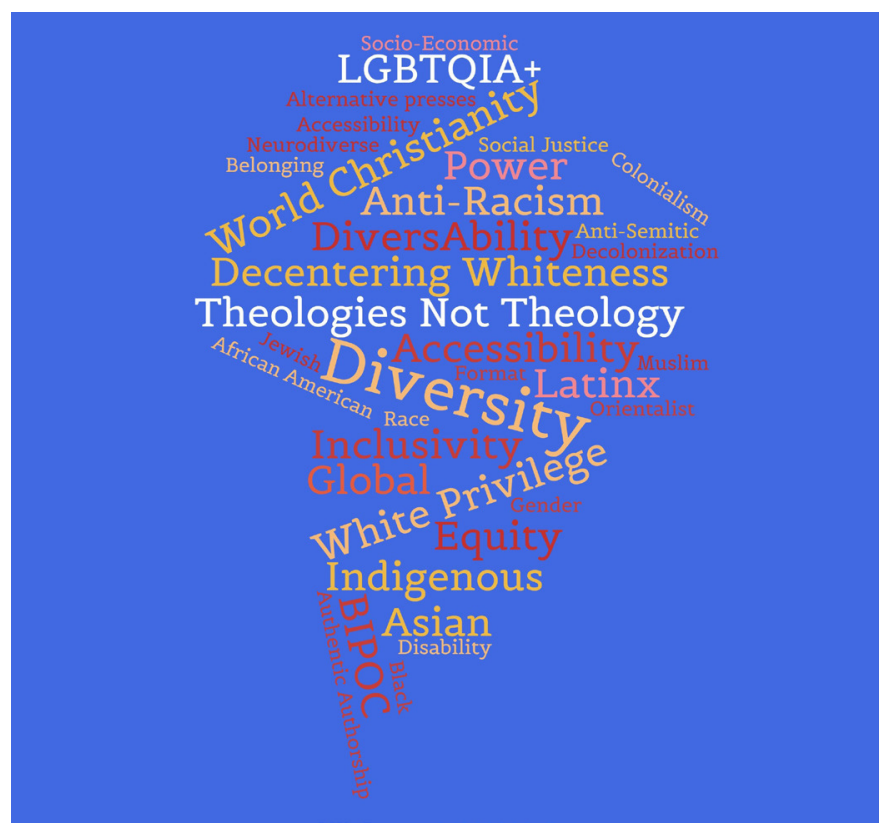


Where to start? If you are in a university context like Yale, diversity can be overwhelming. You not only support the collection development needs of a seminary or divinity school, but also those of other academic departments and a global network of scholars who also rely on your collections. There are multiple constituencies and topics to cover and not only the contemporary American scene, but historical and global aspects. Diverse theological collections should include:

- Publications that engage issues of power, race, ethnicity, sexual orientation, and disability

- Publications representing a variety of theological perspectives

- Publications that reflect the lived, religious experiences of people of different faith traditions

- Publications by authentic authors and about underrepresented groups

- Publications that are global in scope, possibly in multiple languages

To avoid running around in too many directions at once, I recommend laying the groundwork by taking a deep dive into the curriculum. By now I hope that theological librarians have access to course syllabi, but I realize this is still difficult in some contexts. If you don't have access, make a case with the curriculum committee or the academic dean that this is a valuable resource for keeping current and planning for needed course materials. Any new materials not in the library should be ordered, whether for required reading or recommended readings. I like to think of course reserves as ensuring equality for all students in the course. The library's provision of course reserves ensures that every student has equal access to the essential reading required to succeed. However, the library's role doesn't end there. To provide equity, reference works and other research materials must be selected with knowledge of assignments, papers, and other course requirements. These additional materials, like commentaries, reference works, and scholarly monographs, shelved where they are visible and easily accessible, ensure that students have an equitable opportunity to do well.

Does your school have diversity requirements for students? At Yale Divinity School (YDS), M.Div. students have two requirements they must fulfill for graduation:

- Every M.Div. student is required to take one course in a nonChristian religion or one course in the relationship between Christianity and other religions. 
- Every M.Div. student is required to take one course that either focuses on or integrates in a sustained way material on class, gender/sexuality, race/ethnicity, disability, and/or global/ cultural diversity. This course may also include material on globalization.

At YDS, the onus is on the faculty member to demonstrate that their course meets the diversity requirement when the syllabus is submitted for review by the Curriculum Committee. If your school has similar requirements, you may want to concentrate your collecting efforts on these courses.

Finally, I would like to mention a special initiative at YDS that allowed me to gain meaningful insight into the curriculum from the faculty perspective. YDS has a curriculum committee composed of the academic dean, faculty, students, and a librarian. They meet regularly throughout the academic year to approve syllabi for new courses and to draft policies relating to requirements and scheduling.

This year, as part of the Dean's anti-racism initiative, he asked the Curriculum Committee to review the entire curriculum with an eye to guaranteeing that all students would have significant exposure to anti-racism topics while at YDS. The faculty met in teaching groups to evaluate courses in their areas and to make recommendations for change. Each group was asked to reflect on the history of their discipline, evaluate whether their introductory courses met the school's commitment to equity, and to point to a particular course that was exemplary with regard to diversity. Many of the disciplines represented are not those viewed as being particularly diverse, at least not traditionally, including philosophy of religion, biblical studies, ethics, and liturgical studies. Some interesting themes ran through the comments offered by the faculty:

- Almost all acknowledged privileging of Eurocentric, male, white, Christian voices both in the founding and the present composition of the disciplines and in its literatures.

- Many concluded that although the disciplines needed to be open to new, diverse voices, the classic works should not be expunged, but redeployed and re-examined from new perspectives.

- Some admitted that the inclusion of "diversity" topics and readings had been relegated to discussion sessions with teaching assistants and not as part of the professor-led course sessions, signaling to students that this material was of lesser value. 
- There is now a greater commitment to rethinking diversity in the introductory courses.

What this indicates is that diversity will increasingly be a major component of theological education, even in the foundational courses that traditionally have highlighted the thought of white, Eurocentric scholars. Librarians have a critical role to play in these changes, which will radically change our library collections.

\section{DIVERSIFYING THE COLLECTION AT THE BOSTON UNIVERSITY SCHOOL OF THEOLOGY LIBRARY}

Amy Limpitlaw, Boston School of Theology

The Theology Library at Boston University primarily serves the BU School of Theology. The Library's efforts toward creating a collection reflecting a diversity of perspectives and voices are directly related to the School of Theology's larger commitment to diversity, equity, and inclusion, especially as this commitment took shape in recent years. While the BU School of Theology, embracing its self-designation as the "School of the Prophets" (http://www.bu.edu/sth-history/), has enjoyed a long history of attentiveness to issues of social justice, in recent years the School further deepened its explicit commitment to diversity, equity, and inclusion. A brief history of how this came about and the impact on the Theology Library is in order.

The move towards a more explicit commitment to diversity began at a community town hall in 2015. A group of students presented a letter demanding greater diversity among faculty hires. This demand arose after the departure of the sole Black female LGBTQ faculty member. Over the next few years, the School took steps to respond to this challenge. First came the creation of a steering committee on diversity, equity, and inclusion. More focused conversations on the issue were undertaken during community town halls, meetings, and surveys of the community. In 2016, the School instituted a permanent Office of Diversity, Equity, and Inclusion; and a Diversity Statement (http://www.bu.edu/sth/about/diversity-statement/), outlining the School's explicit commitments on this issue, was drafted that same year and voted on and adopted by the faculty in 2017.

The Diversity Statement as adopted makes explicit reference to work of the Theology Library:

The School of Theology will therefore endeavor to nurture a community culture that values inclusive diversity in all its forms, while paying particular scholarly and social attention to the 
intersectionality of race, gender, sexuality, physical ability, learning differences, and global origin, reflecting the strengths of our faculty and staff. To fulfill this mission, the School of Theology will... expect scholarship from people of various races, genders, sexualities, physical abilities, learning differences, theological perspectives, and global origins to be taught in classrooms and, to this end, encourage the STH library to reflect increasingly this diversity in its collections [emphasis added].

The Library in turn has taken steps to affirm the seriousness with which it takes this charge, first by incorporating language from the Diversity Statement into its own mission statement (http://www. bu.edu/sthlibrary/about/):

...in support of the School's commitment to diversity, equity, and inclusion, the Library strives to build a collection that includes works from scholars of various races, genders, sexualities, physical abilities, learning differences, theological perspectives, and global origins.

The Library also reaffirmed its commitment to developing a diverse collection of resources in its collection development policy:

Finally, the Library seeks to build a collection that comprises a diversity of voices and perspectives, including (but not limited to) scholarship from and reflecting the perspectives of people of various races, genders, sexualities, physical abilities, learning differences, theological perspectives, and nationalities.

The actual task of building a collection that "comprises a diversity of voices and perspectives" involves more, of course, than mere statements expressing said commitment. The Library is still working toward this goal, but certain steps have been taken. One step is simply to pinpoint some of the key call numbers and call number ranges as helpful tools for locating and acquiring resources that either deal with issues of diversity or may reflect the scholarship of underrepresented ethnic, racial, gender, and other groups. In Appendix A below, we provide a list (not exhaustive) of some of these call numbers and call number ranges.

Another step is to consider books published in series, either for purchase as individual titles or for subscription to the series as a whole as a standing order. Many publishers are now seeking to highlight the scholarship of underrepresented groups. Book series such as "Asian Christianity in the Diaspora” (Springer-Verlag), "Majority World Theology Series” (Langham), and "Celebrating Faith: Explorations in Latino Spirituality and Theology” (Rowman \& Littlefield) center the work of scholars from distinct backgrounds. A list (again, 
not exhaustive) of some of these book series being published is provided in Appendix B.

The work of the Library in this direction has also been aided by the challenge to faculty to take steps to implement a diversity of voices in their course readings. Syllabi for new courses are reviewed by a faculty committee and returned to faculty members if the course does not include a sufficient diversity of assigned readings. The Library always makes sure its collection includes both required and recommended course readings, so the work of faculty to include a diverse selection of voices in their course has in turn helped the Library to improve the diversity of its collection. Moreover, new courses focused specifically on issues of social justice in relationship to diversity have been created in recent years, and this has likewise led to the acquisition of more resources focused on issues of diversity, equity, and social justice.

The Library also solicits input from the community in the work of collection development. Faculty requests and recommendations of course take priority, but student input is also welcome. The challenge to the School to embody its commitment to diversity came from students, and students have provided some of the most valuable input to the Library in terms of helping the Library diversify its collection. One example of this is the graduating class of 2016, which decided to make their class gift a donation of funds to the Library so that the Library could purchase books related to the theme of "Power, Privilege, and Prophetic Witness." (https://ibrary.bu.edu/sthspecialcollections/classgift2016) Students who donated to the gift fund were given the opportunity to choose a title to be added to the Library's collection, and this collection in turn became the basis for further acquisitions focused on social justice, diversity, equity, and inclusion.

While the work of building a more diverse collection continues, there is the important work of sharing and promoting the collection. This has been undertaken by the Library staff in a number of ways, including the creation of LibGuides. The Library's collection of LibGuides includes the following:

- African-American and Womanist Theologies

- African Theologies

- Asian and Asian-American Theologies

- Disability Theologies

- Evangelical Theologies

- Feminist Theology 
- Interfaith Studies

- Latinx Theologies

- LGBTQUIA Resources and Queer Theologies

New acquisitions are also highlighted at monthly faculty meetings, as well as on the Library's web site. (https://library.bu.edu/ sthnewbooks) And finally, library staff utilize social media such as Twitter and Facebook to highlight diverse collections.

While responding to the challenge to enact its commitment to diversity, equity, and inclusion remains, the Library continues to take steps to build a more diverse collection.

\section{DIVERSITY PROGRAMING AT BARBOUR LIBRARY}

Michelle Spomer, Pittsburgh Theological Seminary

So, you're intentionally building diversity into your collection - how, then, do you connect these resources with library users? How do you foster rich conversations around these resources? This is where library programming comes in, and specifically, diversity programming. This includes drawing attention to and engaging with library resources by and about people with diverse experiences, including (but not limited to) people of color, the LGBTQIA community, people with disabilities, and ethnic, cultural, and religious minorities.

\section{Why Diversity Programming?}

There are several reasons to consider diversity programming:

\section{- Collection Promotion}

First, various types of programming can draw attention to and increase usage of specific resources. Probably, many of you are already promoting your collections through displays, new acquisitions lists, and other means.

\section{- Mission Support}

Diversity programming in the library can support the mission of your institution. While your institution's mission statement may not directly include something about diversity, you may find the idea of diversity in vision statements, core values, strategic plans, or position statements.

\section{- Curricular Support}

Diversity programming can, of course, support the curriculum. There may be learning outcomes, course assignments, courses 
that focus on diversity issues, and guest lectures that would all benefit from programming.

\section{- Institutional Initiatives}

Diversity programming can also complement institutional initiatives. For example, the Pittsburgh Seminary board has recently identified the need for seminary-wide anti-racism initiatives. This initiative has included diversity training, reading groups, and guest lectures, all of which could be supported by library programming.

\section{- Partnerships}

Lastly, diversity programming can be a catalyst for new relationships, and can undergird the variety of programs and events hosted by your institution. Barbour Library has developed fruitful collaborations with the Writing Center, student groups, and Continuing Education. There are several other groups that we hope to partner with for future programming.

\section{Diversity Programming in Barbour Library}

Diversity programming in Barbour Library has really only been happening for about one and a half years, all pre-COVID. Here are a few highlights of what's been done in that time period:

\section{- Events}

Barbour Library has been fortunate to collaborate with two student groups to provide robust programming that included book displays, bibliography handouts, receptions, and online guides. The two student groups are Rainbow Covenant, which supports students in the LGBTQIA community, and Syngeneia, a group that supports students of color. Both collaborations included the following elements:

\section{- Library Resources}

Library staff collaborated with members of both groups to review resources already in the collection, and to identify items that could be added.

\section{- Bibliography Handouts}

A resource list was generated, and print handouts were included in the book displays for people to take with them.

\section{- Resource Displays}

All four endcap display units around the second-floor atrium were used to showcase collection resources, all of which could be checked out. 


\section{- PTS Community Receptions}

The seminary community was invited to a reception in the atrium area, where they could view the book display, enjoy refreshments, and speak with members of the student groups.

\section{- LibGuides}

The final element was creating LibGuides for library users to use well after the event and after the displays were taken down.

\section{- Displays}

In addition to the two events described above, library staff created standalone resource displays that were focused on diversity themes. These included displays for the 150th birthday of Mahatma Ghandi, Native American Heritage Month, and for a seminary event (2020 Kelso Community Conversation on Race and Faith). The first two displays were gleaned from online calendars that list such events (some of these are included in the bibliography for this session). Taking a look at event calendars at your institutions will often yield events that can be complemented by diversity programming.

\section{Ideas for Future Diversity Programming}

Barbour Library staff are looking forward to developing more diversity programming. Here are just a few diversity programming ideas for consideration.

\section{- Diversity Plan}

Many academic libraries have diversity plans that include goals related to strategic planning, welcoming spaces, recruitment and retention of diverse staff, library programming, instruction, and collection development. If you Google "library diversity plan,” you will find many examples of such plans.

\section{- Interactive Displays}

While there are many ways that displays might be interactive, one example that lends itself to diversity programming is a display based on the Race Card Project (https://theracecardproject.com/). Library users are asked to distill their thoughts, experiences, or observations about race into one sentence that has just six words. The sentence is written down and then displayed in some way for other library users to consider. 


\section{- Highlight Resources in the Catalog}

Barbour Library's online catalog homepage includes links to resource lists for various collections (such as new books). A list for diversity resources could be added.

\section{- Displays Designed by Library Users}

Why limit the development of displays to library staff? Students, faculty, staff, and local community members could all be potential resources for creating displays.

\section{- Movie Nights with Discussion}

Space in Barbour Library is a bit limited, but a movie night with discussion could be done on a small scale. There are any number of movies with diversity themes that could spark thought-provoking conversations.

\section{- Art Exhibits}

There are several spaces in Barbour Library that would be great for displaying the work of local artists who touch on themes of diversity.

\section{- Speaker Series}

Barbour Library has just started three different speaker series, all of which could host speakers from diverse backgrounds and/or speakers who engage with diversity issues.

- Performances

Music, dance, and other types of performances could take place in a variety of spaces in Barbour Library.

\section{- Social Media}

Currently, the library has very little exposure through social media platforms. Diversity events and library resources could be promoted via Facebook, Instagram, Twitter, and other platforms.

\section{- Special Collections Exhibits}

While we are currently without an archivist, there are a variety of items in the seminary's institutional archives and special collections that could be used for exhibits with diversity themes.

We are looking forward to planning for more events and programming in Barbour Library centered around themes of diversity. Please 


\section{BIBLIOGRAPHY OF RESOURCES TO SUPPORT DIVERSITY, EQUITY, AND INCLUSION IN YOUR LIBRARY AND ITS COLLECTIONS}

\section{Books and Articles}

\section{Collection Development Issues}

Baildon, Michelle, Dana Hamlin, Czeslaw Jankowski, Rhonda Kauffman, Julia Lanigan, Michelle Miller, Jessica Venlet, and Ann Marie Willer. "Creating a Social Justice Mindset: Diversity, Inclusion, and Social Justice in the Collections Directorate of the MIT Libraries.” Report, February 9, 2017. https://dspace.mit.edu/ handle/1721.1/108771.

Blume, Rachel, and Allyson Roylance. "Decolonization in Collection Development: Developing an Authentic Authorship Workflow." The Journal of Academic Librarianship 46, no. 5 (September 1, 2020): 102175. https://doi.org/10.1016/j.acalib.2020.102175

Bogan, Kelsey. "Diversity Audit: A Practical Guide.” Don't Shush Me! (blog), June 15, 2020. https://dontyoushushme.com/2020/06/15/ diversity-audit-a-practical-guide/ (This relates to high school libraries, but some categories are relevant.)

Bowers, Jennifer, Katherine Crowe, and Peggy Keeran. “'If You Want the History of a White Man, You Go to the Library' : Critiquing Our Legacy, Addressing Our Library Collections Gaps.” Collection Management 42, no. 3-4 (October 2, 2017): 159-79. https://doi.org/ 10.1080/01462679.2017.1329104.

Ciszek, Matthew P., and Courtney L. Young. "Diversity Collection Assessment in Large Academic Libraries.” Collection Building 29, no. 4 (January 1, 2010): 154-61. https://doi. org/10.1108/01604951011088899.

Cruz, Alice M. "Intentional Integration of Diversity Ideals in Academic Libraries: A Literature Review.” The Journal of Academic Librarianship 45, no. 3 (May 1, 2019): 220-27. https:// doi.org/10.1016/j.acalib.2019.02.011. (Includes a section on collections.) 
Customer Services, All Saints. "Guides: Celebrating Diversity: Diversity Audit.” Accessed June 11, 2021. https://libguides.mmu.ac.uk/c. php?g=490273\&p=4828625.

"Diversity \& Inclusivity in Collection Building Workshop Presentations | Colorado Alliance of Research Libraries.” Accessed June 11, 2021. https://www.coalliance.org/diversity-inclusivity-collection-building-workshop-presentations.

Gonzalez, Melissa. "LibGuides: Diversity Collection Assessment 2020: Introduction.” Accessed June 11, 2021. https://libguides. uwf.edu/c.php?g=1057279\&p=7682341.

Herrera, Gail. "Undergraduate Library Collection Use and Diversity: Testing for Racial and Gender Differences.” Portal: Libraries and the Academy 16, no. 4 (2016): 763-74. https://doi.org/10.1353/ pla.2016.0051.

LaFond, Deborah M., Mary K. Van Ullen, and Richard D. Irving. "Diversity in Collection Development: Comparing Access Strategies to Alternative Press Periodicals.” At SUNY Albany 61, no. 2 (March 2000): 136-44.

Vega García, Susan A. "Racial and Ethnic Diversity in Academic Library Collections: Ownership and Access of African American and U.S. Latino Periodical Literature.” The Journal of Academic Librarianship 26, no. 5 (September 1, 2000): 311-22. https://doi. org/10.1016/S0099-1333(00)00137-3.

Wagner, Travis L., and Archie Crowley. "Why Are Bathrooms Inclusive if the Stacks Exclude? Systemic Exclusion of Trans and Gender Nonconforming Persons in Post-Trump Academic Librarianship.” Reference Services Review 48, no. 1 (January 1, 2020): 159-81. https://doi.org/10.1108/RSR-10-2019-0072.

Other Issues Related to Diversity, Equity, and Inclusion and Librarianship "ACRL Equity, Diversity and Inclusion.” Association of College \& Research Libraries. Accessed June 11, 2021. https://acrl.libguides. com/edi.

"ALA Takes Responsibility for Past Racism.” American Libraries (Chicago, Ill.) 51.9-10 (2020): 10. Web. 
Adler, Melissa, and Lindsey M. Harper. "Race and Ethnicity in Classification Systems: Teaching Knowledge Organization from a Social Justice Perspective.” Library Trends 67.1 (2018): 52-73.

Alabi, Jaena. "From Hostile to Inclusive: Strategies for Improving the Racial Climate of Academic Libraries.” Library Trends 67.1 (2018): 131-46.

Alabi, Jaena. "Racial Microaggressions in Academic Libraries: Results of a Survey of Minority and Non-Minority Librarians.” The Journal of Academic Librarianship 41.1 (2015): 47-53.

Alexander, David L. "American Indian Studies, Multiculturalism, and the Academic Library." College \& Research Libraries 74.1 (2013): 60-68.

Arroyo-Ramirez, Elvia, et al. "The Reach of a Long-Arm Stapler: Calling in Microaggressions in the LIS Field through Zine Work.” Library Trends 67.1 (2018): 107-30.

Becker, Jenifer. “Active Allyship.” Public Services Quarterly 13.1 (2017): 27-31.

Berray, Mohamed. “Campus Partnerships for Promoting Equity, Diversity and Inclusion: A Case Study of the NCBI Model for Reducing Prejudice and Intergroup Conflict at Florida State University Libraries.” Journal of Academic Librarianship 45.5 (2019): 1.

Blummer, Barbara, and Jeffrey M. Kenton. “Academic Libraries' Outreach Efforts: Identifying Themes in the Literature.” Public Services Quarterly 15, no. 3 (2019): 179-204. https://doi.org/10.108 0/15228959.2019.1592058.

Bonnet, Jennifer L, and McAlexander, Benjamin. "Structural Diversity in Academic Libraries: A Study of Librarian Approachability.” The Journal of Academic Librarianship 38.5 (2012): 277-86.

Brook, Freeda, Dave Ellenwood, and Althea Eannace Lazzaro. "In Pursuit of Antiracist Social Justice: Denaturalizing Whiteness in the Academic Library." Library Trends 64, no. 2 (Fall, 2015): 246-284. https://www.ideals.illinois.edu/bitstream/ handle/2142/89748/64-2-brook.pdf?sequence=2 . 
Chancellor, Renate L. "Racial Battle Fatigue: The Unspoken Burden of Black Women Faculty in LIS.” Journal of Education for Library and Information Science 60.3 (2019): 182-89.

Chou, Rose L., and Pho, Annie. Pushing the Margins : Women of Color and Intersectionality in LIS. Sacramento, CA: Library Juice, 2018.

Coleman, Anita, PhD. "Using the Anti-Racism Digital Library and Thesaurus to Understand Information Access, Authority, Value and Privilege.” Theological Librarianship 13, no. 1 (04, 2020): 1.

Collins, Anastasia M. "Language, Power, and Oppression in the LIS Diversity Void.” Library Trends 67, no. 1 (Summer, 2018): 39-51.

"Controversy Over Race Erupts at American Library Association Meeting." The Journal of Blacks in Higher Education, 2019-02-06.

Dreher, Tanja and Jemima Mowbray. The Power of One on One: Human Libraries and the Challenges of Antiracism Work. UTS EPRESS, 2012.

"Extended Racial Equity Resource Guide for Libraries.” WebJunction. Accessed June 11, 2021. https://www.webjunction.org/documents/webjunction/racial-equity-guide.html.

Espinal, Isabel, Tonia Sutherland, and Charlotte Roh. "A Holistic Approach for Inclusive Librarianship: Decentering Whiteness in our Profession.” Library Trends 67.1 (2018): 147-62.

Everett, Stephanie. "Visualizing the Silent Dialogue about Race: Diversity Outreach in an Academic Library." Journal of Academic Librarianship 44.4 (2018): 518.

Farkas, Meredith. "Not Beyond Critique.” American Libraries 51.9 (2020): 54.

Galbraith, Quinn, Erin Merrill, and Olivia Outzen. "The Effect of Gender and Minority Status on Salary in Private and Public ARL Libraries.” Journal of Academic Librarianship 44.1 (2018): 75.

Galvan, Angela. "Soliciting Performance, Hiding Bias: Whiteness and Librarianship." In In the Library with a Lead Pipe. http://www. inthelibrarywiththeleadpipe.org/2015/soliciting-performancehiding-bias-whiteness-and-librarianship .

Ghaddar, J. J., and Michelle Caswell. ““To Go Beyond”: Towards a Decolonial Archival Praxis.” Archival Science 19.2 (2019): 71-85. 
Gibson, Amelia N, Chancellor, Renate L, Cooke, Nicole A, Park Dahlen, Sarah, Lee, Shari A, and Shorish, Yasmeen L. "Libraries on the Frontlines: Neutrality and Social Justice.” Equality, Diversity and Inclusion: An International Journal 36.8 (2017): 751-66.

Gorman, Michael. "Dispelling Fear of 'the Other'.” American Libraries 37.4 (2006): 3.

Hall, Tracie D. "Race \& Place: A Personal Account of Unequal Access.” American Libraries 38.2 (2007): 30-3.

Hanna, Kathleen, Robin Crumrin, and Mindy Cooper. Diversity Programming and Outreach for Academic Libraries. Oxford, UK: Chandos Publishing, 2011.

Hauptman, Robert. "Questioning Library Neutrality: Essays from Progressive Librarian.” Journal of Information Ethics 20, no. 1 (Spring, 2011): 135-137.

Honma, Todd. "Trippin' Over the Color Line: The Invisibility of Race in Library and Information Studies." InterActions: UCLA Journal of Education and Information Studies, 1(2). (2005).

Hosoi, Mihoko, Gwen Evans, and Nancy S. Kirkpatrick. "Creating Diversity in Libraries: Management Perspectives.” Library Leadership \& Management (Online) 2020: 1-13.

Hudson, David J. and Kathleen Lowrey. "On Dark Continents and Digital Divides: Information Inequality and the Reproduction of Racial Otherness in Library and Information Studies/Response to Hudson.” Journal of Information Ethics 25, no. 1 (Spring, 2016): 62-82,149.

Hussey, L. “The Diversity Discussion: What Are We Saying?” Progressive Librarian, 34/35 (2010):3-11.

Ishizuka, Kathy. “Talkin’ Bout a Revolution: Libraries, Too, Can Evolve Toward Equity.” School Library Journal 66.7 (2020): 7.

Irvin, Vanessa. “"I Have Two Legs, Not Four”: Navigating the -isms of the LIS Minefield." Journal of Education for Library and Information Science 60.3 (2019): 231-38. Web.

Iverson, S. (2008). "Librarianship and Resistance.” In A. Lewis (Ed.), Questioning library neutrality: Essays from Progressive Librarian. Duluth, MN: Library Juice Press. 
Jiao, Qun G., Anthony J. Onwuegbuzie, and Sharon L. Bostick. "The Relationship between Race and Library Anxiety among Graduate Students: A Replication Study.” Information Processing \& Management 42.3 (2006): 843-51.

Kendrick, Kaetrena Davis, and Damasco, Ione T. "Low Morale in Ethnic and Racial Minority Academic Librarians: An Experiential Study.” Library Trends 68.2 (2019): 174-212.

Knapp, J., Snavely, L., \& Klimczyk, L. (2012). "Speaking Up: Empowering Individuals to Promote Tolerance in the Academic Library.” Library Leadership and Management, 26 no. 1 (2012): 1-21.

Kung, Janice Y., K-L Fraser, and Dee Winn. "Diversity Initiatives to Recruit and Retain Academic Librarians: A Systematic Review." College and Research Libraries (Online) 81, no. 1 (01, 2020): 96.

Lankes, R. David. "Reclaiming Our Virtue: Why in This Time of Crisis Librarians, Authors, Publishers, and Educators Must Commit to Systemic Change.” The Publishers Weekly 267.28 (2020): 20.

“The Libraries' Role in Promoting Diversity, Equity, and Inclusion.” Lafayette College Library. Accessed June 11, 2021. https://library. lafayette.edu/the-librarys-role-in-promoting-diversity-equityand-inclusion/.

Lipsitz, George. "Libraries \& Memories: Beyond White Privilege 101." Progressive Librarian 32 (2009): 3,9,88.

Long, D. "Latino Students' Perceptions of the Academic Library." Journal of Academic Librarianship, 37:6 (2011): 504-511.

Mehra, B., Rioux, K. S., \& Albright, K. S. "Social Justice in Library and Information Science.” In M. J. Bates \& M. N. Maack (Eds.), Encyclopedia of Library and Information Sciences (3rd ed., pp. 4820-4836). London: Taylor \& Francis, 2009.

Mestre, L. S. "Librarians Working with Diverse Populations: What Impact Does Cultural Competency Training Have on Their Efforts?” Journal of Academic Librarianship, 36.6 (2010): 479-488.

Morales, Myrna, Em Claire Knowles, and Chris Bourg. "Diversity, Social Justice, and the Future of Libraries." Portal : Libraries and the Academy 14.3 (2014): 439-51. 
Neely, T. Y., \& Peterson, L. "Achieving Racial and Ethnic Diversity among Academic and Research Librarians: The Recruitment, Retention, and Advancement of Librarians of Color" [ACRL white paper]. College \& Research Libraries News [Online], Volume 68 Number 9 (1 October 2007.) https://crln.acrl.org/index.php/ crlnews/article/view/7869.

Noble, Safiya Umoja. Algorithms of Oppression. New York: NYU, 2018.

Noor, Tamara. "Roundtable: What is Holding Librarianship Back from being More Inclusive of Visible Minorities?” Partnership: The Canadian Journal of Library and Information Practice and Research 13, no. 2 (2018): 1-6.

Overall, P. M. (2009). "Cultural Competence: A Conceptual Framework for Library and Information Science Professionals." Library Quarterly, 79(2), 175-204.

Pashia, Angela. "Black Lives Matter in Information Literacy." Radical Teacher (Cambridge) 113 (2019): 100-02.

Pashia, Angela. "Examining Structural Oppression as a Component of Information Literacy: A Call for Librarians to Support \#BlackLivesMatter through our Teaching.” Journal of Information Literacy 11.2 (2017): 86.

Pawley, Christine. "Unequal Legacies: Race and Multiculturalism in the LIS Curriculum.” The Library Quarterly 76.2 (2006): 149.

Poole, Alex H. “"Could My Dark Hands Break through the Dark Shadow?”: Gender, Jim Crow, and Librarianship during the Long Freedom Struggle, 1935-1955.” The Library Quarterly (Chicago) 88.4 (2018): 348-74.

"Programming to Promote Diversity.” American Library Association, March 10, 2021. Accessed June 11, 2021. https://www.ala.org/ advocacy/diversity/culturalprogrammingtopromotediversity. RUSA, Working Group. "From Committees of RUSA: RUSA Adopts Statement on Equity, Diversity, and Inclusion.” Reference \& User Services Quarterly 58.1 (2018): 52.

Scardilli, Brandi. "Calls for Equity and Diversity at ALA

Virtual.” Information Today 37.6 (2020): 12-15. 
Schadt, Erin M. "Racial Equity in the Library, Part One: Where to Start?” WebJunction. WebJunction, June 1, 2020. Accessed June 11, 2021. https://www.webjunction.org/news/webjunction/racialequity-partone.html.

Schadt, Erin M. "Racial Equity in the Library, Part Two: Diverse Collections, Programming, Resources.” WebJunction. WebJunction, May 15, 2017. Accessed June 11, 2021. https://www.webjunction.org/news/webjunction/racial-equity-parttwo.html.

Schlesselman-Tarango, Gina. "How Cute! Race, Gender, and Neutrality in Libraries." Partnership: the Canadian Journal of Library and Information Practice and Research 12.1 (2017): 1-18.

Shachaf, P., \& Horowitz, S. "Are Virtual Reference Services Color Blind?” Library and Information Science Research, 28 no. 4 (2006): 501-520.

Shachaf, Pnina, and Mary Snyder. "The Relationship between Cultural Diversity and User Needs in Virtual Reference Services.” Journal of Academic Librarianship 33.3 (2007): 361-7.

Sierpe, Eino. "Confronting Librarianship and its Function in the Structure of White Supremacy and the Ethno State.” Journal of Radical Librarianship 5 (2019). https://journal.radicallibrarianship.org/index.php/journal/article/view/39 .

Skinner, S., and B. Martin. "Racist Disinformation on the World Wide Web: Initial Implications for the LIS Community.” Australian Library Journal 49.3 (2000): 259-69.

Sweeney, Miriam E, and Cooke, Nicole A. "You're So Sensitive! How LIS Professionals Define and Discuss Microaggressions Online.” The Library Quarterly (Chicago) 88.4 (2018): 375-90.

Sweeper, Darren, and Steven A. Smith. "Assessing the Impact of Gender and Race on Earnings in the Library Science Labor Market.” College \& Research Libraries 71.2 (2010): 171.

Sweeper, Darren, and Steven A. Smith PhD. "Does Gender and Race have an Impact on Earnings in the Library and Information Science Labor Market in the United States of America?” LIBRES: Library and Information Science Research Electronic Journal 20.2 (2010): 1-21. 
Teo, Kam. "African American Librarians of the Far West." Libraries \& the Cultural Record 43.4 (2008): 494-5.

"University Libraries Diversity Action Plan.” University of Tennessee Libraries, January 21, 2021. Accessed June 11, 2021. https://www. lib.utk.edu/wp-content/uploads/sites/15/files/2021/03/UT-Libraries-DAP-Revision-Jan21-2021.pdf.

Velez, LaTesha, and Melissa Villa-Nicholas. "Mapping Race and Racism in U.S. Library History Literature, 1997-2015.” Library Trends 65.4 (2017): 540-54.

West, Jessamyn. "Data-Driven Discriminating Librarianship." Computers in Libraries 38.2 (2018): 14-16.

Wheeler, Maurice B, and Smith, Daniella. "Race and Leadership in Library and Information Science Education: A Study of African American Administrators.” Library Trends 67.1 (2018): 23-38. Whitmire, E. (2003). "Cultural diversity and undergraduates' academic library use.” Journal of Academic Librarianship, 29(3), 148-161.

Whitmire, Ethelene. "The Campus Racial Climate and Undergraduates' Perceptions of the Academic Library." Portal : Libraries and the Academy 4.3 (2004): 363-78.

Winston, Mark. "Diversity: An Ethical Question with Competing Rationales.” Journal of Information Ethics 23.1 (2014): 83-100. Yorio, Kara. "Librarians Join Protests: With Signs, Books, and Passion, Educators Support Black Lives Matter.” School Library Journal (New York, N.Y.) 66.7 (2020): 14.

\section{Online Resources}

Asian-American Christian Collaborative - Reading List https://www.asianamericanchristiancollaborative.com/recommended-resources

BU School of Theology Library: African-American and Womanist Theologies

https://library.bu.edu/sthaawt

BU School of Theology Library: African Theologies https://library.bu.edu/sthafrica 
BU School of Theology Library: Asian and Asian-American Theologies

https://library.bu.edu/sthasia

BU School of Theology Library: Disability Theologies

https://library.bu.edu/sthdisability

BU School of Theology Library: Latinx Theologies

https://library.bu.edu/sthlatinx

BU School of Theology Library: LGBTQIA+ Resources and Queer Theologies

https://library.bu.edu/sthlgbtqia

BU School of Theology Library: Interfaith Studies

https://library.bu.edu/sthinterfaith

BU School of Theology Library: Prophetic Witness

https://library.bu.edu/sthpropheticwitness

LGBTQIA Library Resources: Rainbow Covenant Resource Collection https://guides.pts.edu/rainbow

A Latinx Theology Reading List

https://sojo.net/articles/latinx-theology-reading-list

Syngeneia Resource Collection

https://guides.pts.edu/syngeneia

Calendars for Display \& Event Planning

Diversity for Social Impact: Global Cultural \& Festival Celebration

Calendar

https://diversity.social/diversity-calendar-events/

Library of Congress: Commemorative Observances

https://www.loc.gov/law/help/commemorative-observations/index.

php

National Today: National Day Calendar

https://nationaltoday.com/national-day-calendar/ 
Truckee Meadows Community College (TMCC): Diversity Awareness

Calendar

https://www.tmcc.edu/diversity/awareness-calendar

\title{
APPENDIX A: COLLECTING AREAS TO FOCUS ON FOR DIVERSITY, EQUITY, AND INCLUSION
}

\author{
African and African-American \\ BR563.N4 Christianity - History -- African Americans \\ BR1360 Christianity - History -- Africa \\ BS521.2 Bible - Criticism and interpretations - Black \\ interpretations \\ BT82.7 Theology -- Black theology \\ BT83.9 Theology-Womanism \\ BV2783 Practical theology - Missions - African- \\ Americans \\ BV4080 - BV4085 Practical theology - Training for the ordained \\ ministry - Education of African-American \\ ministers \\ BV4468.2.A34 Practical theology - Practical church work - \\ Church work with African-Americans \\ BV4468.2.B55 Practical theology - Practical church work - \\ Church work with Blacks (outside the U.S.) \\ BX1407.N4 Christian denominations - African Americans \\ BX6447-BX6460 Christian denominations - African-American \\ Baptists \\ BX8440-BX8449 Christian denominations - African Methodist \\ Episcopal Church \\ BX8450-BX8459 Christian denominations - African Methodist \\ Episcopal Zion Church \\ E185.5-E185.98 United States - African-Americans \\ ML3186.8-ML3187 Literature on Music - Sacred Vocal Music - \\ Christian -- Gospel \\ ML3556 Literature on Music-African-American \\ Asian and Asian-American
}

BR563.A82 Christianity - History - United States -- AsianAmericans 


\begin{tabular}{|c|c|}
\hline BR563 .K67 & stianity - History - United \\
\hline BR1060-BR1357 & Christianity - History - Asia \\
\hline T83.58 & Theology-Minjung Theology \\
\hline V2787 & $\begin{array}{l}\text { Practical Theology - Missions - Immigrants -- } \\
\text { Chinese }\end{array}$ \\
\hline V2788.J3 & $\begin{array}{l}\text { Practical Theology - Missions - Immigrants - } \\
\text { Japanese }\end{array}$ \\
\hline BV2788.V53 & $\begin{array}{l}\text { Practical Theology - Missions - Immigrants - } \\
\text { Vietnamese }\end{array}$ \\
\hline BV3460-BV3462 & $\begin{array}{l}\text { Practical Theology - Missions - Immigrants - } \\
\text { Korean }\end{array}$ \\
\hline BV4468.2.A74 & $\begin{array}{l}\text { Practical theology - Practical church work - } \\
\text { Church work with Asian Americans }\end{array}$ \\
\hline BV4468.2.K6 & $\begin{array}{l}\text { Practical theology - Practical church work - } \\
\text { Church work with Korean Americans }\end{array}$ \\
\hline BX1615-BX1673 & $\begin{array}{l}\text { Christian denominations -- Catholic Church - } \\
\text { Asia }\end{array}$ \\
\hline BX4857-BX4861 & Christian denominations - Protestantism - Asia \\
\hline E184.A75 & United States - Asian Americans \\
\hline E184.J3 & United States - Japanese \\
\hline E184.K6 & Inited States -- Koreans \\
\hline \multicolumn{2}{|l|}{ Latinx } \\
\hline BL2540-BL2 & $\begin{array}{l}\text { History of Religion - Latin America, Central } \\
\text { America, South America }\end{array}$ \\
\hline BR563.H57 & Christianity - Hispanic Americans \\
\hline BR600-BR73 & $\begin{array}{l}\text { Christianity - History -- Latin America/South } \\
\text { America }\end{array}$ \\
\hline BT83.575 & Theology-Hispanic-American theology \\
\hline BT83.57 & Theology-Liberation Theology \\
\hline BT83.583 & Theology - Mujerista Theology \\
\hline BV4468.2.H57 & $\begin{array}{l}\text { Practical Theology - Church work with Hispanic } \\
\text { Americans }\end{array}$ \\
\hline BV4468.2.M48 & $\begin{array}{l}\text { Practical Theology - Church work with Mexican } \\
\text { Americans }\end{array}$ \\
\hline BX1407.H55 & Christian denominations - Hispanic Americans \\
\hline BX1425-BX148 & $\begin{array}{l}\text { Christian denominations - Catholic Church - } \\
\text { Latin America, Central America, West Indies, } \\
\text { South America }\end{array}$ \\
\hline
\end{tabular}


BX4832.5-BX4836 Christian denominations - Protestantism - Latin America, Central America, West Indies, South America

BX1795.E44

E184.C34

E184.M5

E184.S75

Christian denominations - Catholic Church Emigration and Immigrations

United States - Central Americans

United States -- Mexicans

United States - Spanish Americans, Hispanic Americans, Latin Americans

\section{LGBTQIA}

BL65.H47

BL65.H64

BL65.S4

BM729.H65

BR115.H6

BR115.T76

BS680.H67

BS680.S5

BS1186.5

BS2545.H63

BT83.65

BT708

BV4437.5

BV4596.G38

BX1795.H66

BX8349.H66

BX8385.H65
Religion in relation to heterosexism

Religion in relation to homosexuality

Religion in relation to sex

Judaism - Homosexuality

Christianity -- Homosexuality

Christianity - Transvestism, Transsexualism

The Bible-Homosexuality

The Bible - Sex

The Bible - Criticism and Interpretation - Gay Interpretations

The Bible - New Testament - Homosexuality

Theology - Queer Theology

Theology-Sex

Practical Theology - Church work with Gays, Lesbians, Bisexuals

Practical Theology -- Gays

Catholic Church -- Homosexuality

Methodism -- Homosexuality .

Methodism - Homosexuality

Disability Theology

BL625.9.P45

BL625.9.P46

BS680.P435

BS1199.A25

BT732.7

BV1615.D4

BV1615.D48
Religion - People with disabilities

Religion - People with mental disabilities

Bible - People with disabilities

Bible - Old Testament - People with disabilities

Theology - Suffering, Affliction, Pain

Practical Theology - Religious Education - Deaf

Practical Theology - Religious Education Developmentally disabled children 


\begin{tabular}{|c|c|}
\hline BV16 & $\begin{array}{l}\text { Practical Theology-Religious Education - People } \\
\text { with disabilities }\end{array}$ \\
\hline BV1615.M37 & $\begin{array}{l}\text { Practical Theology-Religious Education-People } \\
\text { with mental disabilities }\end{array}$ \\
\hline BV1615.M4 & $\begin{array}{l}\text { Practical Theology - Religious Education - } \\
\text { Children with mental disabilities }\end{array}$ \\
\hline BV1615.S6 & $\begin{array}{l}\text { Practical Theology - Religious Education - } \\
\text { Children with social disabilities }\end{array}$ \\
\hline BV4335-BV4338 & $\begin{array}{l}\text { Practical Theology-Pastoral theology-Service } \\
\text { to the sick, suffering, and people with disabilities }\end{array}$ \\
\hline BV4460-BV4463 & $\begin{array}{l}\text { Practical Theology - Church work with people } \\
\text { with disabilities }\end{array}$ \\
\hline \multicolumn{2}{|c|}{ Other Call Numbers to Consider } \\
\hline BL6 & in \\
\hline BL65.E75 & Religion in relation to ethnicity, ethnic relation \\
\hline BL65.R3 & Religion in relation to race \\
\hline BR115.E45 & Christianity - Emigration and Immigration \\
\hline BR115.G59 & Christianity-Globalization \\
\hline BS521.86 & $\begin{array}{l}\text { The Bible - Criticism and interpretation } \\
\text { postcolonial criticism }\end{array}$ \\
\hline BS680.E38 & The Bible - Emigration and Immigration \\
\hline BT83.593 & Theology - Postcolonial theology \\
\hline BT734.2 & Theology - Race relations \\
\hline BT83.65 & gy-Queer theology \\
\hline BV639.I4 & Practical Theology - Immigrants \\
\hline BV639.M56 & Practical Theology - Minorities \\
\hline BV639.P6 & Practical Theology - the Poor \\
\hline BV2784-BV2788 & Practical Theology - Missions - Immigrants \\
\hline BV4466 & Practical Theology - Church work with refugee \\
\hline HV645 & $\begin{array}{l}\text { Church work with refugees, including the } \\
\text { Sanctuary Movement }\end{array}$ \\
\hline [V6001-JV & Immigration and Emigration \\
\hline
\end{tabular}




\section{APPENDIX B: BOOK SERIES TO SUPPORT BUILDING DIVERSE COLLECTIONS}

1. Series Title: African Christian Studies Series

Publisher: Wipf and Stock

Web Site: https://wipfandstock.com/searchresults/?series=african-christian-studies-series

2. Series Title: African Practical Theology

Publisher: Wipf \& Stock

Web Site: https://wipfandstock.com/searchresults/?series=african-practical-theology

3. Series Title: African Theological Studies

Publisher: Peter Lang

Web Site: https://www.peterlang.com/view/serial/ ATS?rskey=LlQcnx\&result $=16$

4. Series Title: Africana Religions

Publisher: Penn State University Press

Web Site: https://www.psupress.org/books/series/book_ SeriesAfRel.html

5. Series Title: African Theology

Publisher: LIT Verlag

Web Site: https://www.lit-verlag.de/publikationen/reihen/ afrikanische-theologie-african-theology-theologie-africaine/

6. Series Title: American Indian Catholics

Publisher: University of Notre Dame Press

Web Site: https://undpress.nd.edu/ books/?series=american-indian-catholics

Notes: $\quad$ Series is complete, last book in series was published in 1999.

7. Series Title: Arabic Christianity

Publisher: Brill

Web Site: https://brill.com/view/serial/ACTS

8. Series Title: Africa Bible Commentary Series

Publisher: Langham

Web Site: https://langhamliterature.org/books?series_ $\mathrm{id}=4070$ 
9. Series Title: Africa Society of Evangelical Theology Series

Publisher: Langham

Web Site: https://langhamliterature.org/books?series_ id $=4329$

10. Series Title: Asia Bible Commentary Series

Publisher: Langham

Web Site: https://langhamliterature.org/books?series_ $\mathrm{id}=4026$

11. Series Title: Asian Christianity in the Diaspora

Publisher: Springer-Verlag / Palgrave Macmillan

Web Site: http://www.springer.com/series/14781

12. Series Title: Bible and Theology in Africa

Publisher: Peter Lang

Web Site: https://www.peterlang.com/view/serial/

BTA?rskey=hQqvBp\&result $=1$

13. Series Title: Bible in Africa Studies

Publisher: University of Bamberg Press

Web Site: https://www.uni-bamberg.de/ubp/verlagsprogramm/reihen/bible-in-africa-studies/

14. Series Title: Bishop Henry McNeal Turner/Sojourner Truth Series in Black Religion

Publisher: Orbis

Notes: $\quad$ Not available on publisher's web site, but can be found on Gobi.

15. Series Title: Bloomsbury Studies in Religion, Gender, and Sexuality

Publisher: Bloomsbury Academic

Web Site: https://www.bloomsbury.com/uk/series/bloomsbury-studies-in-religion-gender-and-sexuality/

16. Series Title: Celebrating Faith: Explorations in Latino Spirituality and Theology

Publisher: Rowman \& Littlefield

Web Site: https://rowman.com/Action/SERIES//CBF/Celebrating-Faith:-Explorations-in-Latino-Spirituality-and-Theology:

17. Series Title: Christian Heritage Rediscovered $<$ New Delhi : Christian World Imprints> 
Publisher: Biblia Impex Pvt. Ltd. / Christian World Imprints Web Site: https://www.christianworldimprints.com/index. php?

Notes: $\quad$ Publisher is based in New Delhi, India, and is focused on "publishing books on all aspects related to Christian Studies on or from all continents."

18. Series Title: Christianities of the World

Publisher: Springer-Verlag / Palgrave Macmillan

Web Site: http://www.springer.com/series/14893

19. Series Title: Christianity in Modern China

Publisher: Springer-Verlag

Web Site: https://www.palgrave.com/us/series/14895

20. Series Title: Claremont Studies in Interreligious Dialogue Publisher: Claremont Press

Web Site: https://claremontpress.com/index.html

21. Series Title: Comparative Theology: Thinking across Traditions

Publisher: Fordham University Press

Web Site: https://www.fordhampress.com/series/comparative-theology-thinking-across-traditions/

22. Series Title: A Constructive Christian Theology for the Pluralistic World

Publisher: Eerdmans

Web Site: https://eerdmans.com/Products/CategoryCenter. aspx?CategoryID=SE!CCTPW

23. Series Title: Contrapuntal Readings of the Bible in World Christianity

Publisher: Pickwick Publications / Wipf \& Stock

Web Site: https://wipfandstock.com/searchresults/?series=contrapuntal-readings-of-thebible-in-world-christianity

24. Series Title: Currents of Encounter: Studies on the Contact between Christianity and other Religions, Beliefs, and Cultures / Studies in Interreligious and Intercultural Relations 
Publisher: Brill

Web Site: http://www.brill.com/products/series/currentsencounter

25. Series Title: Dimensions of Asian Spirituality

Publisher: University of Hawai'i Press

Web Site: https://uhpress.hawaii.edu/bookseries/dimensions-of-asian-spirituality/

26. Series Title: Edinburgh Companions to Global Christianity

Publisher: Edinburgh University Press

Web Site: https://edinburghuniversitypress.com/seriesedinburgh-companions-to-global-christianity

27. Series Title: Encountering Traditions

Publisher: Stanford University Press

Web Site: https://www.sup.org/books/ series/?series=ENCOUNTERING\%20TRADITIONS

28. Series Title: Gender, Theology, and Spirituality

Publisher: Routledge

Web Site: https://www.routledge.com/Gender-Theology-and-Spirituality/book-series/GTS) https:// edinburghuniversitypress.com/series-edinburgh-companions-to-global-christianity

29. Series Title: Gendering the Study of Religion in the Social Sciences

Publisher: Routledge

Web Site: https://www.routledge.com/Gendering-theStudy-of-Religion-in-the-Social-Sciences/bookseries/GSRSS

30. Series Title: Global Christian Library

Publisher: Langham

Web Site: https://langhamliterature.org/books?series_ $\mathrm{id}=4026$

31. Series Title: Global Pentecostal and Charismatic Studies

Publisher: Brill

Web Site: http://www.brill.com/publications/global-pentecostal-and-charismatic-studies

32. Series Title: Global Perspectives on Biblical Scholarship Publisher: SBL Press 
Web Site: https://www.sbl-site.org/publications/Books_ GPBS.aspx

33. Series Title: Global Perspectives Series

Publisher: Langham

Web Site: https://langhamliterature.org/books?series_ $\mathrm{id}=4026$

34. Series Title: Intercultural Theology

Publisher: Intervarsity Press

Web Site: https://www.ivpress.com/intercultural-theologyvol-one

35. Series Title: Intercultural Theology and Study of Religions

Publisher: Brill

Web Site: https://brill.com/abstract/serial/

ITSR?rskey=eRUJCg\&result $=654$

36. Series Title: International Studies in Religion and Society

Publisher: Brill

Web Site: https://brill.com/abstract/serial/

ISRS?rskey=0ZURVY\&result=705

37. Series Title: International Voices in Biblical Studies

Publisher: SBL Press

Web Site: https://www.sbl-site.org/publications/Books_ IVBS.aspx

38. Series Title: Internationale Theologie / International Theology

Publisher: Peter Lang

Web Site: https://www.peterlang.com/view/serial/IT

39. Series Title: Interreligious Reflections

Publisher: Rowman and Littlefield

Web Site: https://rowman.com/Action/SERIES/_IRR/Interreligious-Reflections

40. Series Title: Interreligious Studies

Publisher: Lit Verlag

Web Site: https://www.lit-verlag.de/publikationen/reihen/ interreligious-studies/

41. Series Title: Interreligious Studies in Theory and Practice Publisher: Palgrave Macmillan 
Web Site: https://www.springer.com/series/14838

42. Series Title: Jewish Latin America Series

Publisher: University of New Mexico Press

Web Site: https://unmpress.com/Jewish_Latin_America_ Series

43. Series Title: Majority World Theology Series

Publisher: Langham

Web Site: https://langhamliterature.org/books?series_ $\mathrm{id}=4188$

44. Series Title: Martin Luther King, Jr. Memorial Studies in Religion, Culture and Social Development

Publisher: Peter Lang

Web Site: https://www.peterlang.com/view/serial/ MLK?rskey=nHYQAz\&result $=991$

45. Series Title: Mission in Global Community

Publisher: Baker Book House

Web Site: http://bakerpublishinggroup.com/series/ mission-in-global-community

46. Series Title: Missional Church, Public Theology, World Christianity

Publisher: Pickwick Publications / Wipf and Stock

Web Site: https://wipfandstock.com/searchresults/?series=missional-church-public-theology-world-christianity

47. Series Title: Nanzan Library of Asian Religion and Culture

Publisher: Nanzan Institute of Religion and Culture / University of Hawai'i Press

Web Site: https://nirc.nanzan-u.ac.jp/en/publications/ nlarc/

48. Series Title: New Approaches to Religion and Power

Publisher: Springer-Verlag

Web Site: http://www.springer.com/series/14754

49. Series Title: New and Alternative Religions

Publisher: NYU Press

Web Site: https://nyupress.org/search-results/?series=newand-alternative-religions 
50. Series Title: New Perspectives in Latina/o Religion

Publisher: Baylor University Press

Web Site: https://www.baylorpress.com/searchresults/?series=new-perspectives-on-latinaoreligion

51. Series Title: Notre Dame History of Hispanic Catholics in the U.S.

Publisher: University of Notre Dame Press

Web Site: https://undpress.nd.edu/books/?series=notredame-history-of-hispanic-catholics-in-the-u-s

52. Series Title: Notre Dame Studies in African Theology Publisher: University of Notre Dame Press

Web Site: https://undpress.nd.edu/books/?series=notredame-studies-in-african-theology

53. Series Title: Postcolonial and Decolonial Studies in Religion and Theology

Publisher: Lexington Books / Rowman \& Littlefield

Web Site: https://rowman.com/Action/SERIES/_LEXSRT/ Postcolonial-and-Decolonial-Studies-in-Religionand-Theology

54. Series Title: Postcolonialism and Religions

Publisher: Springer-Verlag

Web Site: http://www.springer.com/series/14535

55. Series Title: Pathways for Ecumenical and Interreligious Dialogue

Publisher: Palgrave Macmillan

Web Site: https://www.palgrave.com/us/ series/14561

56. Series Title: Prophetic Christianity

Publisher: Eerdmans

Web Site: https://www.eerdmans.com/Products/CategoryCenter.aspx?CategoryId=SE!PC

57. Series Title: RaceReligion

Publisher: Stanford University Press

Web Site: https://www.sup.org/books/ series/?series=RACERELIGION 
58. Series Title: Religion and Development in Southern and Central Africa

Publisher: Mzuni Press

59. Series Title: Religion and Gender

Publisher: Routledge

Web Site: https://www.routledge.com/Religion-andGender/book-series/SE0680

60. Series Title: Religion and Society in Africa

Publisher: Peter Lang

Web Site: https://www.peterlang.com/view/serial/RSA

61. Series Title: Religion in Modern Africa

Publisher: Routledge

Web Site: https://www.routledge.com/Religion-in-ModernAfrica/book-series/ARELAFRICA

62. Series Title: Religion in the Americas

Publisher: Brill

Web Site: http://www.brill.com/publications/religionamericas-series

63. Series Title: Religion, Race and Ethnicity

Publisher: NYU Press

Web Site: https://nyupress.org/searchresults/?series=religion-race-and-ethnicity

64. Series Title: Religion, Resistance, Hospitalities

Publisher: Routledge

Web Site: https://www.routledge.com/Religion-ResistanceHospitalities/book-series/RELRESHOS

65. Series Title: Religions of the Americas Series

Publisher: University of New Mexico Press

Web Site: https://unmpress.com/Religions_of_the_Americas_Series

66. Series Title: Religions of the World

Publisher: Routledge

Web Site: https://www.routledge.com/Religions-of-theWorld/book-series/SE0381

67. Series Title: Religious Cultures of African and African Diaspora People 
Publisher: Duke University Press

Web Site: https://www.dukeupress.edu/books/browse/ by-series/series-detail?IdNumber $=2877705$

68. Series Title: Research in Religion and Family: Black Perspectives

Publisher: Peter Lang

Web Site: https://www.peterlang.com/view/serial/

RRF?rskey=s4IyKw\&result $=576$

69. Series Title: Routledge Critical Studies in Religion, Gender, and Sexuality

Publisher: Routledge

Web Site: https://www.routledge.com/Routledge-CriticalStudies-in-Religion-Gender-and-Sexuality/bookseries/RCSRGS

70. Series Title: Routledge Inform Series on Minority Religions and Spiritual Movements

Publisher: Routledge

Web Site: https://www.routledge.com/Routledge-InformSeries-on-Minority-Religions-and-SpiritualMovements/book-series/AINFORM

71. Series Title: Routledge Studies in Asian Religion Publisher: Routledge

Web Site: https://www.routledge.com/Routledge-Studiesin-Asian-Religion/book-series/SE0535

72. Series Title: Routledge Studies in Asian Religion and Philosophy

Publisher: Routledge

Web Site: https://www.routledge.com/Routledge-Studiesin-Asian-Religion-and-Philosophy/book-series/ RSARP

73. Series Title: Routledge Studies on Religion in Africa and the Diaspora

Publisher: Routledge

Web Site: https://www.routledge.com/Routledge-Studieson-Religion-in-Africa-and-the-Diaspora/bookseries/RSRAD

74. Series Title: Studies in Chinese Christianity 
Publisher: Pickwick Publications

Web Site: https://wipfandstock.com/searchresults/?series=studies-in-chinese-christianity

75. Series Title: Studies in Religion, Theology, and Disability

Publisher: Baylor University Press

Web Site: https://www.baylorpress.com/searchresults/?series=studies-in-religion-theology-anddisability

76. Series Title: Studies in the History and Culture of World Christianities

Publisher: Wipf and Stock

Web Site: https://wipfandstock.com/searchresults/?series=studies-in-the-history-andculture-of-world-christianities

77. Series Titles: Studies in the History of Christianity in the Non-Western World

Publisher: Otto Harrassowitz Verlag

Web Site: https://www.harrassowitz-verlag.de/seriessequence_259.ahtml

78. Series Title: Studies in the Intercultural History of Christianity

Publisher: Peter Lang

Web Site: https://www.peterlang.com/view/serial/

IC?rskey $=$ cChUe7\&result $=1590$

79. Series Title: Studies in World Catholicism

Publisher: Wipf and Stock / Cascade Books

Web Site: https://wipfandstock.com/searchresults/?series=studies-in-world-catholicism

80. Series Title: Studies in World Christianity

Publisher: Baylor University Press

Web Site: https://www.baylorpress.com/searchresults/?series=studies-in-world-christianity

81. Series Title: Studies in World Christianity

Publisher: Wipf and Stock

Web Site: https://wipfandstock.com/searchresults/?series=studies-in-world-christianity 
82. Series Title: Studies in World Christianity and Interreligious Relations

Publisher: Brill /Routledge

Web Site: https://brill.com/abstract/serial/

WCIR?rskey $=$ PXfKv4\&result $=137$

83. Series Title: Studies in world Christianity and interreligious relations

Publisher: Taylor \& Francis

Web Site: http://208.254.74.112/books/series/WCIR/

84. Series Title: Study of Religion in a Global Context

Publisher: Equinox Publishing

Web Site: https://www.equinoxpub.com/home/the-studyof-religion-in-a-global-context/

85. Series Title: Theology and Mission in World Christianity

Publisher: Brill

Web Site: http://www.brill.com/products/series/theologyand-mission-world-christianity

86. Series Title: Theology in Africa

Publisher: LIT Verlag

Web Site: https://www.lit-verlag.de/publikationen/reihen/ theology-in-africa/

87. Series Title: Understanding World Christianity

Publisher: Augsburg Fortress Press

Web Site: https://www.fortresspress.com/store/category/287088/Understanding-World-Christianity

88. Series Title: Women in Religion Series

Publisher: NYU Press

Web Site: https://nyupress.org/searchresults/?series=women-in-religions

89. Series Title: World Christianity

Publisher: Penn State University Press

Web Site: https://www.psupress.org/books/series/book_ SeriesWC.html 